\title{
DUFRENNE, HUMANISM AND ANTIHUMANISM
}

This paper will discuss the French philosopher Mikel Dufrenne's defense of humanism. When the history of this period is finally written, the struggle between humanism and antihumanism will appear as one of the central problems of our time, indeed of the entire modern period, not only in philosophy. It seems obvious that what is called progress has often been bought at great human cost, leading not to less but rather to more human alienation, however understood, as the real condition of the development of modern industrial civilization.

This problem is central to Dufrenne's life and work. Dufrenne is widely known in France and in the United States for his groundbreaking contribution to phenomenological esthetics as well as for his view of the a priori. In France, he is also well known for his defense of humanism in the late 1960s in a moment when it was, as it is now, only slightly more unpopular to oppose antihumanism in theory than in practice.

Dufrenne's commitment to humanism is doubly determined both politically and philosophically. His commitment to philosophical humanism derives from his strong political interest in a better life for all people. For Dufrenne, philosophy does not reduce to, but also cannot be isolated from, politics, of which it was the natural extension. Like many other French intellectuals of his generation, he took very seriously the idea of the intellectual responsibility of intellectuals, which he understood as' a personal comittment which influenced his philosophical writings. Without ever reducing philosophy to mere ideology, he strove to enlist it as a means toward realizing the general goal of a better world for all men and women.

Dufrenne was not a Marxist in any obvious sense, although his political commitment often led him toward Marxism, although more on a political than a philosophical plane. Unlike so many 
Marxists and even non-Marxists, who talk about man in the abstract, Dufrenne was interested, not in an abstract concept, but rather in concrete human beings. Like many other intellectuals, he rallied to a certain French view of Marxist humanism. This is the same Marxist humanism which was criticized by Maurice Merleau-Ponty as in practice falling short of the ideal when the Stalinist purges became known, which was reaffirmed as an ideal by Jacques-Yves Calvez, and which was later criticized again, but in an infinitely more superficial way, by the socalled new philosophers (Henri-Lévy, Lardieu, Glucksmann, Jean-Marie Benoit, and so on). In France, institutional Marxism was represented by the French Communist Party, which attracted many intellectuals after the War until the student revolution in the late $1960 \mathrm{~s}$, and which remained strong until it was defeated in a series of deft political maneuvers in the early 1980 s by François Mitterand. Although Dufrenne was severely critical of the French Communist Party, he remained committed to a certain ideal conception of Marxism, which, even now, after the sudden, unforeseen decline of the Soviet bloc, continues to attract French intellectuals. ${ }^{1}$

Dufrenne's personal and philosophical commitment to aa certain conception of humanism was determined as well by the broadly humanist character of the French intellectual tradition. Humanism in general has two main meanings, including the revival of ancient learning during the Renaissance, and the concern with a certain conception of human being as conceptually central. At least since the sixteenth century, French philosophy has always centered on a conception of the subject. This is already a main theme in the writings of such early modern French philosophers as Michel Montaigne and René Descartes, in Enlightenment figures like Denis Diderot and Condorcet (pseud. of Marie Jean Antoine de Caritat), and then more recently in Jean-Paul Sartre, Merleau-Ponty, and even Martin Heidegger, the central "French" philosopher since the War. ${ }^{2}$

Traditional French intellectual humanism played an

1. See, e. g. Jacques Derrida, Spectres de Marx, Paris: Editions Galilée, 1993.

2. See Tom Rockmore, Heidegger and French Philosophy: Humanism. Antihumanism and Being, London: Routledge, 1995. 
important role in Heidegger's emergence as the dominant philosopher in the French context. Since the historical context is increasingly obscured by time, it is often overlooked that Heidegger's decisive breakthrough in French philosophy occurred immediately after the War in the outcry provoked by Sartre's famous popular lecture, Existentialism is a Humanism. ${ }^{3}$ If Sartre's aim was to provoke, then he clearly succeeded. His lecture provoked not only Catholics made uneasy by his Marxism, but also Heideggerians concerned with his tendentious reading of his own theory as continuous with Heidegger's, leading finally to Heidegger's own effort, in his Letter on Humanism, to dissociate his view from Sartre's.

How is it that an obscure German thinker, highly critical of French thought, convinced that when the French think they think in German, since, by implication they cannot think in their own language, a known Nazi, could replace Sartre as the French master thinker after the War? The answer in part lies in the fact that at a time when Being and Time, Heidegger's main treatise had not been translated into French, his Letter on Humanism, which was in fact a letter to the French in his time of need when he was being called to account for his Nazism, presented his theory as a new and deeper humanism. The answer in part further lies in the French Heideggerian effort to reject Sartre's unprecedented hegemonic role in French philosophy and literature while providing a different, more accurate view of Heidegger's contribution. It should not be overlooked that Sartre's controversial claim that his theory was continuous with Heidegger's still rankled so much that many years later at the end of the 1960s it was still a major theme for Jacques Derrida, who, after Beaufret's death, became the central French defender and student of Heidegger's thought. ${ }^{4}$

Heidegger's conception of humanism has attracted a lot of attention, particularly in the wake of the appearance of Victor Farías book, Heidegger and Nazism, whose appearance in 1987 sparked an

3. See Jean-Paul Sartre, L'existentialisme est un humanisme, Paris: Nagel, 1964.

4. See "Les fins de l'homme," in Marges de la philosophie, Paris: Les Editions de Minuit, 1972, pp. 129-164. 
immense controversy. ${ }^{5}$ In reaction to the Farías book, Luc Ferry and Alain Renaut published a sharp attack on socalled French antihumanism, ${ }^{6}$ which appeared in 1988, twenty years after the French student revolution. Ferry and Renaut aim to diagnose a link between Heidegger's antihumanism, understood as the rejection of modernity, and the supposedly basic error of contemporary French philosophy. The book contains an unusually direct critique of French Heideggerianism divided into three sub-types, First, there is the zero degree, which is represented by Beaufret's denial of any relation between Heidegger and Nazism, Second, there is Heideggerian orthodoxy, which admits that the early Heidegger was not yet free of the metaphysics of subjectivity. And, third, there is unorthodox Heideggerianism, which illustrated by Derrida, who finally differs from the orthodox variant in strategy only.

The renewed attention to Heidegger's Nazism in the wake of the Farías book occurred long after Dufrenne's book had appeared. Neither Nazism nor Heidegger is the explicit focus of his study. Unlike many other French intellectuals, Dufrenne never became obsessed with Heidegger and never wavered from his support for a rather different kind of humanism. Dufrenne's concern with a better life for all human beings, hence with humanism as distinguished from antihumanism, found expression politically in his stand in favor of different issues over the years, such as his defense of the French language. Like many other intellectuals, he linked his defense of the language to a certain vision of France and the French. This same concern is the basis of his interesting book, which has never been translated, Pour l'homme. Since the term "l'hommme" in French, which has no easy equivalent in English, refers indiscriminately to both sexes, the title can be very roughly rendered into English as For Men and Women.

The central theme of the book is indicated in the very first sentence, where he writes: "This essay proposes to discuss the antihumanism intrinsic to contemporary philosophy and to defend

5. See Victor Farías, Heidegger et le nazisme, Paris: Editions Verdier, 1987.

6. See Luc Ferry and Alain Renaut, La pensée 68, Essai sur l'anti-humanisme contemporain, Paris: Gallimard, 1988. 
against it the idea of a philosophy which would be concerned with men and women [qui aurait souci de l'homme]." ${ }^{77}$ Here Dufrenne understands antihumanism in a wide sense including not only philosophical theories which diminish the importance of the subject as well as political practices which develop the interests of some people at the expense of others.

His book came out during the Vietnamese War, which was highly unpopular in France. As a group, French intellectuals of all persuasions were united in their opposition to what they regarded, to use the jargon of the period, as the imperialist aggression of the United States against the Vietnamese. It is then not by chance that there are repeated references throughout the book to the courage of the Vietnamese people.

The discussion develops in two roughly equal parts, including an account of some main themes in contemporary French philosophy at the time he was writing in the late 1960s and a sketch of a humanist theory, ending in a postface on the prospects for men and women today. As concerns antihumanism, Dufrenne's main point is that, in ways linked to their own positions, many contemporary philosophers and others turn away from human beings in developing their ideas. According to Dufrenne, who is mainly concerned with French philosophy, in which Heidegger played a dominant role after the War, Heidegger's ontology, Lévi-Strauss's structural anthropology, Lacan's psychoanalysis and Althusser's Marxism share a "separation from [mise à l'écart] and dissolution of human being." 8

In support of this view, Dufrenne provides a rapid but very broad discussion of the state of French philosophy in the late 1960s, which he regards as basically antihumanist. His main targets in order of importance seem to be first Althusser, second Foucault, and third Heidegger. Throughout he simply assumes that epistemology, by which he means contemporary French epistemology inspired by Bachelard, is simply incompatible with taking human subjectivity seriously.

7. Mikel Dufrenne, Pour l'homme, Paris: Editions du Seuil, 1968, p. 9.

8. Dufrenne, Pour l'homme, p. 10.

9. See Dufrenne, Pour l'homme, e. g. p. 192. 
In his review of contemporary philosophy, Dufrenne finds antihumanism, a term on loan from Althusser, virtually everywhere in the discussion. It is, to begin with, a staple of Althusser's famous antihumanist reading of Marx's theory, through a creative application of Bachelard's idea of an epistemological break (coupure épistémologique). According to Althusser, Marx's early philosophical humanism later gave way to a scientific antihumanism in which the real subject is not men and women but the structures of modern capitalism. In drawing the consequences of this approach, Dufrenne points out that Althusser's epistemological reading of Marx reduces the theory to an epistemology ${ }^{10}$ based on the evacuation of the real subject.

Antihumanism is further present in Foucault's archeological epistemology, which Dufrenne reads as intending to found the sciences through the analysis of the articulation and function of what Foucault, in L'archéologie du savoir, ${ }^{11}$ calls episteme. ${ }^{12}$ According to Dufrenne, in claiming that human being is a relatively recent invention the early Foucault simply replaces real men and women by concepts in his theory. ${ }^{13}$ Dufrenne sees this tendency at work in the free-floating character of episteme, which, in Foucault's discussion, is unrelated to the historical context. ${ }^{14}$

Dufrenne's remarks on Heidegger follow the widespread French anthropological reading of the latter's theory based on the influence within the French context of his Letter on Humanism, which was initially formulated as a letter to the French philosopher Jean Beaufret. We recall that in distinguishing his analysis of Dasein from the human sciences in Being and Time,${ }^{15}$ Heidegger leaves open the possibility of a new kind of philosophical anthropology. In basing himself on the later Heidegger, Dufrenne correctly points out that in the philosophy of being, which he regards as positivist, human being

10. See Dufrenne, Pour l'homme, p. 49.

11. See Michel Foucault, L'archéologie du savoir, Paris: Gallimard, 1969.

12. See Dufrenne, Pour l'hommme, p.38.

13. See Dufrenne, Pour l'homme, pp. 42, 156

14. See Dufrenne, Pour l'homme, p. 110.

15. See Martin Heidegger, Being and Time, translated by John Macquarrie and Edward Robinson, Evanston: Harper and Row, 1962, §10, pp. 71-76. 
is thought through being as opposed to thinking being through human being. ${ }^{16}$

In the book, Dufrenne makes a start toward overcoming philosophical antihumanism in a very rapid sketch of a philosophy of human being. His conception of humanism encompasses a commitment to fulfilling lives of individual people as well as to a suitably anthropological approach to philosophy, which accepts its social responsibilities in taking shape as a form of human discourse between people about the world and human beings. ${ }^{17}$

In restating the philosophical importance of human being, Dufrenne develops ideas drawn from Emmanuel Levinas, Karl Jaspers, Paul Ricoeur, and others. Breaking with Heidegger, he follows Levinas in regarding ethics as prior to ontology. ${ }^{18} \mathrm{In}$ Dufrenne's view, a person is not and cannot be reduced to a concept, although only a person can entertain concepts or recognize another human being. ${ }^{19}$ According to Dufrenne, any philosophy of human being must turn on a philosophy of the will, or ethics, or better a phenomenology of ethics whose aim is to show how men and women can realize themselves, ${ }^{20}$ not ideally but really. ${ }^{21}$ As Georges Canguilhem has pointed out, not only do biology and medicine presuppose anthropology, but anthropology rests on ethics, that is values realized in the constitution of the cognitive object. ${ }^{22}$

I believe that Dufrenne is correct to see humanism as deeper than antihumanism, which presupposes the subject it supposedly "deconstructs" as the condition of its deconstruction. His diagnosis of the antihumanist turn in recent French philosophy following the turn to Heidegger is largely correct. Certainly the turn away from human being is pandemic in recent French philosophy which, in that respect, simply parts company with one of the central themes of the entire French philosophical tradition. Since Dufrenne did not work out his

16. See Dufrenne, Pour l'homme, p. 23.

17. See Dufrenne, Pour l'homme, pp. 122-123.

18. See Dufrenne, Pour l'homme, p. 153.

19. See Dufrenne, Pour l'hommme, p. 155.

20. See Dufrenne, Pour l'homme, p. 191.

21. See Dufrenne, Pour l'homme, p. 202.

22. See Dufrenne, Pour l'homme, p. 223. 
view of human being in detail here or in subsequent works, I will confine my remarks to his account of forms of antihumanism in French philosophy, which calls for three comments intended not to criticize but rather to supplement his own remarks.

To begin with, I would suggest that the antihumanism running throughout much French structuralism can be traced back to the fantastic influence of the later Heidegger in France after the War. When Heidegger's Nazism was debated during the late 1940s in the pages of Les Temps Modernes, the danger this represented for the acceptance of his philosophy in French philosophy was quickly and effectively defused. In the French debate, the mistaken conviction that Heidegger was basically a humanist philosopher, perhaps of a new, deeper kind, remained remarkably intact until the appearance of Farías's book. Since that time, French philosophers, who uncritically regarded fundamental ontology as basically humanist in spite of Heidegger's questionable political past, have begun a rapid retreat from the rampant Heideggerianism dominant in French philosophy since the 1960 s.

Heidegger's philosophy is difficult to grasp, especially for those who read his texts in translation. Can it be that the well known French humanist reading of Heidegger was based on a misunderstanding of his position? It is worth remembering that after the famous but obscure turning in his thought, perhaps even as a result of it, Heidegger rejects humanism as the term is usually understood, which he simply equates with philosophical anthropology, and further "deconstructs" the "essence of historical man" which he misleadingly compares to a "fleeting cloud shadow over a concealed land."23

Heidegger's controversial reading of Descartes, which is already important in his initial position, forms the basis of his later antihumanism. Recent French discussion of Descartes tends to regard Heidegger's critique of the Cartesian view of the subject as neglecting

23. See "The Age of the World Picture," in Martin Heidegger, The Question Concerning Technology and Other Essays, translated by William Lovitt, New York: Harper and Row, 1977, p. 153. 
the existential dimension as resting on a distortion. ${ }^{24}$ Yet fidelity to the text has never been a primary concern either of Heidegger or of his followers. In rejecting Descartes's supposed anthropological tendency, which appears to be a clear misreading, Heidegger's antihumanist ${ }^{25}$ view of human being as determined by being was widely adopted in the context of the French effort to escape from centuries of Cartesian thought. It is certainly no acccident that a version of Heidegger's later view of the subject recurs in Foucault's famous suggestion that what he calls man will disappear "like a face drawn in the sand at the edge of the sea." ${ }^{26}$

Second, there is the problem of the relation of epistemology and human being. A robust conception of the human subject is not incompatible with epistemology in general. It is only incompatible with a particularly widespread and influential form of epistemology, in practice that form of epistemology which since Plato's Republic has continued to dominate the entire philosophical tradition. Platonic epistemology stresses a normative conception of knowledge as unrevisable, in a word as absolute, hence as beyond the cognitive capacities of finite human beings. This normative view of knowledge, influentially restated at the dawn of the modern tradition by Descartes, goes back in the tradition at least until Platonism, that is the influential series of philosophical ideas routinely but uncritically attributed to Plato, as opposed to Plato's own theory.

The early adoption of a view of knowledge as absolute is linked in the philosophical tradition with two other equally influential features of Platonism. On the one hand, there is the tendency, which is very strong in modern philosophy, to understand the cognitive subject as a function of what we mean by knowledge, for instance in Descartes, Kant, and Husserl. Such philosophers exemplify the widespread approach to the cognitive subject simply in terms of the

24. See Michel Henry, Généalogie de la psychanalyse, Paris: Presses universitaire de France, 1985; see also "Le cogito s'affecte-il?," in Jean-Luc Marion, Questions cartésiennes, Paris: Presses universitaires de France, 1991, pp. 153-188.

25. See Luc Ferry and Alain Renaut, Heidegger et les modernes, Paris: Grasset, 1999.

26. Michel Foucault, Les Mots et les choses: Une Archéologie des sciences humaines, Paris: Editions Gallimard, 1966, p. 398. 
requirements of knowledge as such. Yet if knowledge is human knowledge, then the only real subject is a human being. The proper approach is to understand human knowledge as a function of known human cognitive abilities, not human being as a function of the requirements of knowledge. Since human beings are shaped by their historical context, this leads to a historical view of human knowledge, whose main condition, as Dufrenne clearly saw, is a historical view of human beings.

On the other hand, at least since Plato there is the view that, when it is understood as a source of truth independent of time and place, philosophy is not only relevant, but even indispensable for the good life. Over the centuries this general view has led philosophers to insist on the political utility of merely doing philosophy, and even to intervene in politics. Yet as the efforts at political intervention by Heidegger and Georg Lukács remind us, the political efforts of even the most important philosophers have rarely been as convincing as their theories. Further, the claim for the political utility of philosophy is more often advanced than cogently argued. There seems to be no good reason to follow Immanuel Kant or Edmund Husserl in contending that, say, the defense of what philosophers understand as reason is sufficient either to defeat great evil or even generally socially useful.

For philosophy to live up to its billing as socially indispensable or even useful for the good life, we must understand it, not as independent from, but rather as intrinsically related to, the context in which it emerges and to which it seeks to return. The proper approach for philosophical humanism is not to abandon the problem of knowledge, which has long been the main theme of the philosophical tradition. It is rather to notice the incompatibility of a certain view of knowledge with a historical conception of human being while working toward a postfoundationalist conception of knowledge based on a historical conception of human being.

This leads up to my third remark concerning Dufrenne's general defense of humanism against antihumanism. What progress has been made since the late 1960s when his book was written? Much of this century has been taken up with a confrontation between 
sharply opposing views of the political and economic conditions of social progress as represented by liberal democracy and various forms of totalitarianism, including official Marxism, but also National Socialism, and so on. It is no secret that the further development of industrial capitalism, leading to the still recent collapse of official Marxism, has created an unprecedented situation in which economic liberalism now for the first time clearly dominates the entire planet. Presently, the social prospects for most of humanity simply stand or fall on the results of an involuntary Pascalian wager on the social interest of a system only contingently related to particular human interests. In the United States, we are presently still in a period of unprecedented, or nearly unprecedented economic expansion when paradoxically the very possibility of a rise in real wages is regarded as the main destabilizing economic factor. The difference between the way the economic and political system functions when it is functioning well and its meaningfulness for individuals is visible in the United States in the presently widening inequality between the rich and the poor, in the increasing spread of poverty, especially among young children, in the inability to provide or at least the widerspread resistance to providing health insurance for an important segment of the population, and so on.

On the other hand, the development of French philosophy since the late 1960s has led away from antihumanism, although not toward humanism as Dufrenne conceives it. The rise of poststructuralism and the renewed discussion of what can neutrally be called the Heidegger case offer interesting illustrations. In simplistically associating the very idea of system with terrorism, French poststructuralism rejects any form of overarching explanation. Yet to refuse what Lyotard's calls a méta-récit is part of the rise in irrationalism following from the turn to Heidegger's view of Friedrich Nietzsche. ${ }^{27}$ It would be very difficult, for instance, to defend the inference that geometry, the most systematic form of science, is also the most dangeous form of terrorism.

As a result of the widespread current retreat from Heidegger

27. See Alain Boyer and others, Pourquoi nous ne sommes pas nietzschéens, Paris: Grasset, 1991. 
to religion now underway in French philosophy, especially French phenomenology, ${ }^{28}$ French thinkers are in the process of substituting an effort to understand human beings in terms of God, for instance in the writings of Jean-Luc Marion or Rémi Brague, instead of being. This general effort can be described as a qualified return to Blaise Pascal, who, more than Descartes, centuries ago was concerned to grasp human being through divine being. ${ }^{29}$

This religous turn is not unexpected; as there was no Luther in France, there is not and never has been a clear separation between philosophy and theology. One should not forget that the struggle between partisans of religious and secular humanism, which earlier opposed students of Descartes, continues unabated throughout French culture. If our concern is only humanism, then the return of religious humanism certainly represents progress. Yet if our concern is human being, not God, as Dufrenne clearly saw, the main problem is still to find a way to understand philosophy solely in terms of human being in order to render it useful to men and women.

Duquesne University

TOM ROCKMORE

28. See Dominique Janicaud, Le Tournant théologique de la phénoménologie française, Combas: Editions de l'Eclat, 1991.

29. Marion has always seen Pascal as more important than Descartes for a Christian thinker. See Jean-Luc Marion, Sur le prisme métaphysique de Descartes, Paris: Presses universitaires de France, 1986. 